\title{
MIKROENKAPSULASI EKSTRAK BUAH BUNI SEBAGAI FOOD SAFETY COLOURING
}

\author{
Syamsinar ${ }^{1)}$, Nawalu Saputri ${ }^{1)}$, Risnayanti' ${ }^{1)}$, Michrun Nisa ${ }^{1)}$ \\ ${ }^{1)}$ Akademi Farmasi Kebangsaan Makassar \\ Jln. Perintis Kemerdekaan KM 13,Daya,Makassar 90242 \\ Email : mnmichrunnisa84@gmail.com
}

\begin{abstract}
Dyes in food can increase consumer acceptance of a product, but many synthetic dyes can cause damage to body organs if consumed continuously. Therefore the use of natural ingredients as food coloring needs to be developed. Anthocyanins in Bunny fruits are dyes that can be used as an alternative to synthetic dyes that are safe for health. In this study 3 formulas were made with extract concentrations of 1\%, 2\% and 3\% using 10\% maltodextrin. The lack of anthocyanin stability is formulated into microencapsulation which can provide protection against anthocyanins. The resulting micrograph has almost the same color characteristics as the Buni fruit, which is red to purple. The best stability of microcapsules can be seen in formulas with $1 \%$ extract concentration, absorption efficiency value is $78.26 \%$, after SEM analysis a uniform pore microstructure is obtained compared to other formulas.
\end{abstract}

Key Words : Anthocyanins, microencapsulation, buni fruits, frezee drying, maltodextrin

\begin{abstract}
ABSTRAK
Pewarna dalam makanan dapat meningkatkan penerimaan konsumen terhadap suatu produk, namun banyak pewarna sintesis dapat menyebabkan kerusakan organ tubuh jika dikonsumsi terus menerus. Oleh sebab itu pemanfaatan bahan alami sebagai pewarna makanan perlu dikembangkan. Antosianin dalam buah Buni merupakan zat warna yang dapat dijadikan sebagai alternatif pengganti pewarna sintetis yang aman bagi kesehatan. Pada penelitian ini dibuat 3 formula dengan konsentrasi ekstrak $1 \%, 2 \%$ dan $3 \%$ dengan menggunakan maltodekstrin $10 \%$. Kurangnya stabilitas antosianin maka diformulasi kedalam bentuk mikroenkapsulasi yang dapat memberikan perlindungan pada antosianin. Mikrograf yang dihasilkan memiliki karakteristik warna yang hampir sama dengan buah Buni yaitu berwarna merah hingga ungu. Kestabilan dari mikrokapsul yang paling baik dapat dilihat pada formula dengan konsentrasi ekstrak $1 \%$, nilai efisiensi penyerapan sebesar 78,26\%, setelah analisis SEM diperoleh bentuk mikrostruktur pori yang seragam dibandingkan dengan formula yang lain.
\end{abstract}

Kata kunci : antosianin, mikroenkapsulasi, buah Buni, frezee drying, maltodekstrin 


\section{PENDAHULUAN}

Pewarna merupakan faktor penting yang menentukan ketertarikan konsumen terhadap suatu produk. Kebanyakan dari pewarna yang digunakan adalah pewarna sintetik yang dapat menyebabkan efek samping bagi kesehatan (Lestario dkk, 2011).

Penelitian Badan POM (2008-2010), ditemukan penggunaan bahan tambahan makanan yaitu pewarna berbahaya dalam produksi makanan. Pewarna yang digunakan adalah Rhodamin B, pada pengambilan sampel di industri kerupuk ditemukan sebesar 57 industri kerupuk yang menggunakan pewarna berbahaya. Dari hasil penelitian Sri Sugiyatmi (2006), pada produsen kerupuk di Kabupaten Demak mengenai perilaku produsen, terdapat $84 \%$ produsen yang pengganti pewarna sintetik. Antosianin mengandung banyak senyawa fenolik, yaitu flavonoid yang merupakan pigmen alami yang menyebabkan buah ini memiliki banyak warna seperti kuning, merah, ungu, dan biru (Wijayanti, 2016).

Ekstraksi antosianin dapat dilakukan dengan beberapa jenis pelarut seperti air, methanol, tetapi yang paling efektif adalah dengan menggunakan metanol yang di asamkan dengan $\mathrm{HCl}$. Tetapi karena sifat toksik dari metanol biasanya dalam sistem pangan di gunakan air atau etanol yang di asamkan dengan $\mathrm{HCl}$ (Francis, 1982 : Yu Gao and Cahoon, 1998). Penelitian Amelia (2013), diperoleh hasil penggunaan pelarut etanol $70 \%$ dengan penambahan asam sitrat $3 \%$ merupakan kombinasi terbaik dalam proses ekstraksi.

Stabilitas antosianin tidak hanya dipengaruhi oleh suhu pemanasan pada proses pengolahan saja, namun juga dipengaruhi oleh faktor intrinsik dan ekstrinsik dalam produk, seperti $\mathrm{pH}$, suhu berpengetahuan baik menggunakan pewarna Rhodamin B.

Maraknya penggunaan pewarna makanan yang di larang terutama pada jajanan pasar membuat konsumen merasa khawatir terhadap aspek keamanan pangan, oleh sebab itu perlu adanya alternatif penggunaan pewarna pada makanan (Nursaerah, 2010).Oleh karena itu pewarna alami yang berasal dari ekstrak tanaman (buah, bunga, umbi dan daun), hewan dan mineral menjadi penting untuk kita kembangkan (Amelia dkk, 2013).

Buah Buni merupakan salah satu tanaman tropis yang tumbuh di Indonesia.Buah Buni mengandung vitamin, antosianin, flavonid, dan asam fenolat. Antosianin dalam buah buni merupakan pigmen alami bisa menjadi alternatif penyimpanan, struktur kimia dan konsentrasi antosianin yang ada, keberadaan cahaya, oksigen, enzim, protein, dan ion logam (Rein, 2005). Oleh karena itu perlu dilakukan proses perlindungan terhadap ekstrak buah buni yang mengandung antosianin.

Mikroenkapsulasi adalah suatu teknik penyalutan bahan padat, cairan, dan gas menjadi kapsul dengan ukuran partikel mikroskopik (diameter 1-800 $\mu \mathrm{m}$ ) dengan membentuk salutan dinding tipis disekitaran bahan yang akan dijadikan kapsul. Mikroenkapsulasi dapat memberikan perlindungan pada antosianin dari faktor-faktor fisik, dapat menurunkan laju degradasi, dan mempertahankan penyimpanan pewarna dalam waktu yang lama (Ernawati, 2010). Freeze drying merupakan metode mikroenkapsulasi paling efektif untuk pewarna karena cocok untuk pigmen sensitif, metode ini juga praktis dan ekonomis (Laokuldilok dan Kanha, 2016). 
Maltodekstrin adalah polimer yang umum digunakan pada proses pengeringan menggunakan Freeze Drying, tidak hanya diaplikasikan pada makanan tapi juga digunakan pada industri farmasi (Tresia dkk, 2016). Maltodekstrin merupakan polimer yang baik dalam mikroenkapsulasi karena memiliki sifat daya larut yang tinggi, mengalami dispersi cepat, membentuk sifat higroskopis yang rendah, menghambat kristalisasi, memiliki daya ikat yang kuat dan bobot molekul rendah sehingga dapat mempertahankan produk tetap beku.

\section{METODE PENELITIAN}

Alat

Sampel buah Buni (Antidesma bunius L) yang diperoleh dicuci pada air mengalir, kemudian ditiriskan. Setelah sisa air pencucian ditiriskan, sampel dilanjutkan ke tahapan ekstraksi.

\section{Penyiapan Ekstrak}

Ekstraksi buah buni dilakukan dengan metode maserasi yaitu sampel sebanyak $100 \mathrm{~g}$ dihaluskan, kemudian dimasukan kedalam wadah kaca warna coklat dan ditambahkan etanol 70\% sebanyak 1000 $\mathrm{mL}$ yang diasamkan dengan asam sitrat 3\%. Maserasi dilakukan pada suhu kamar ditempat yang gelap selama selam 24 jam.Disaring filtratnya dengan menggunakan kertas whatman No 1. Filtrat yang diperoleh diuapkan dengan menggunakan rotary vakum evaporator sehingga didapatkan ekstrak kental etanol.Ekstrak yang diperoleh disimpan dalam lemari pendingin suhu $10^{\circ} \mathrm{C}$ dengan wadah yang terlindung cahaya.

\section{Uji Kualitatif ekstrak antosianin}

Analisis kualitatif antosianin
menggunakan metode kromatografi lapis
Alat - alat yang digunakan dalam penelitian ini adalah alat - alat gelas, alat homogenizer, batang pengaduk, cawan porselin, cawan petri, frezee drying, kertas whatman, labu volumetrik, $\mathrm{pH}$ meter, rotary vakum evaporator, sendok tanduk, spatel, Spektrofotometri uv-vis, Scanning Electron Microscopy (SEM), vial dan wadah kaca coklat.

Bahan - bahan yang di gunakan dalam penelitian ini adalah aquadest, asam sitrat, asam klorida, buah Buni ( Antidesma bunius L), Lempeng KLT, Larutan Buffer Fosfat-Asam Sitrat, Etanol $70 \%$, etanol 90 $\%$, Maltodekstrin dan Natrium hidroksida.

\section{Penyiapan Sampel}

tipis (KLT) silika gel F 254 dengan pelarut asam asetat, asam asetat glasial dan asam format dengan perbandingan (100: 11: 11: $26 \mathrm{v} / \mathrm{v} / \mathrm{v} / \mathrm{v})$ untuk menentukan warna antosianin dalam ekstrak

\section{Uji Fitokimia Antosianin}

Uji fitokimia dilakukan untuk mengidentifikasi senyawa antosianin berupa uji warna yang menggunakan pelarut $\mathrm{HCl}$ dan $\mathrm{NaOH}$. Ekstrak antosianin buah buni 0,5 g ditambahkan $\mathrm{HCl} 2 \mathrm{M} 5$ mL kemudian dipanaskan selama 5 menit. Hasil positif bila terjadi perubahan warna menjadi merah.Juga ditambahkan $\mathrm{NaOH} 2$ M tetes demi tetes sambil diamati perubahan warna yang terjadi.Hasil positif bila timbul warna menjadi hijau biru yang memudar perlahan-lahan (Meidayanti dkk, 2015).

\section{Analisis Kandungan Antosianin Total}

Analisis kandungan antosianin dilakukan dengan metode $\mathrm{pH}$ Differential.Sejumlah volume tertentu dari ekstrak buni dilarutkan dalam dua larutan buffer yang berbeda. Larutan pertama dilarutkan 
dengan $0,025 \mathrm{M}$ buffer $\mathrm{KCl} \mathrm{pH} 1,0$ dan larutan lainnya dilarutkan dalam $0,4 \mathrm{M}$ buffer natrium asetat $\mathrm{pH}$ 4,5. Jumlah sampel yang digunakan diatur sehingga menghasilkan absorbansi pada $\lambda$ vis-maks memberikan nilai absorbansi yang berada pada rentang linier dari spektrofotometer. Dilakukan pula scanning panjang gelombang pada rentang $510 \mathrm{~nm}-750 \mathrm{~nm}$ untuk larutan sampel pada kedua buffer ( $\mathrm{KCl}$ dan Natrium Asetat) untuk determinasi kandungan antosianin dan penentuan $\lambda$ vis-maks pengukuran sampel. Selanjutnya dilakukan pengukuran absorbansi masing-masing larutan dan hasilnya dikalkulasikan berdasarkan persamaan berikut (Tensiska, 2014).

$\mathrm{A}=\left(\mathrm{A}_{510}-\mathrm{A}_{700} \mathrm{pH} 1,0-\left(\mathrm{A}_{510}-\mathrm{A}_{700}\right)\right.$ $\mathrm{pH} 4,5$

Konsentrasi antosianin total kemudian dihitung dengan menggunakan rumus:

$\mathrm{TAC}=\underline{\mathrm{A}} \times \mathrm{MW} \times \mathrm{DF} \times \underline{\mathrm{V}} \times 100 \%$ $\varepsilon \times \mathrm{L}$ wt

\begin{tabular}{|l|c|c|c|}
\hline Formula & F1 & F2 & F3 \\
\hline $\begin{array}{l}\text { Ekstrak } \\
\text { buah buni }\end{array}$ & $1 \%$ & $2 \%$ & $3 \%$ \\
\hline $\begin{array}{l}\text { Maltodeks } \\
\text { trin }\end{array}$ & $10 \%$ & $10 \%$ & $10 \%$ \\
\hline Aquadest & $\begin{array}{c}\text { Add } 100 \\
\mathrm{~mL}\end{array}$ & $\begin{array}{c}\text { Add } \\
100 \mathrm{~mL}\end{array}$ & $\begin{array}{c}\text { Add } 100 \\
\mathrm{~mL}\end{array}$ \\
\hline
\end{tabular}

ket:

A : Absorbansi larutan

MW :berat molekul sianidin-3 glukosida

$\varepsilon \quad:$ Absortivitas molar cyaniding-3 glucoside

1 : lebar kuvet $(1 \mathrm{~cm})$

$V d \quad$ : volume akhir penenceran

Wd : berat ekstrak (g). (Supriyadi dan Rujita 2012).

\section{Penentuan Intensitas Warna dari Ekstrak Buah Buni}

Metode yang digunakan mengadaptasi dari FAO (1984) untuk menentukan intensitas warna antosianin dari buah Buni. Larutan buffer fosfat-asam sitrat $\mathrm{pH} 3$ digunakan untuk melarutkan sampel. Panjang gelombang maksimum diukur dengan mengencerkan $20 \mathrm{mg}$ sampel dalam labu volumetrik $25 \mathrm{ml}$ menggunakan Larutan buffer fosfat-asam sitrat $\mathrm{pH}$ 3. Selanjutnya, absorbansi diukur sedemikian rupa sehingga nilai absorbansi berkisar antara 0,2 sampai 0,7 . Buffer digunakan sebagai blanko.

\section{Uji Stabilitas dari Ekstrak Buah Buni}

Stabilitas ekstrak dari buah buni dievaluasi dengan metode perbedaan pH.Dua milliliter sampel dilarutkan dalam $100 \mathrm{~mL}$ larutan buffer asam sitrat dengan $3 \mathrm{pH}$ yang berbeda ( $\mathrm{pH} \mathrm{4,} 5$ dan 7).Absorbansi dari sampel diukur pada panjang gelombang 510-550 nm.

\section{Formulasi Mikrograf dari Ekstrak Buah Buni}

Rancangan formula mikroenkapsul ekstrak buah buni

\section{Analisis Scanning Electron Microscopy (SEM)}

Bentuk dan morfologi permukaan mikroenkapsulasi diamati dengan Scanning Electron Microscopy (SEM).Mikrokapsulasi di coating dengan logam emas menggunakan fine coater dibawah vakum dan sampel diuji dengan Scanning Electron Microscopy (SEM).

\section{Efisiensi Mikroenkapsulasi}

Dilakukan analisis efisiensi mikroenkapsulasi yang dibagi dalam dua 
bagian yaitu jumlah antosianin total dan jumlah antosianin permukaan menggunakan metode yang diadaptasi dari penelitian.

Jumlah total antosianin (TAC) sama dengan $100 \mathrm{mg}$ sampel, direkonsitusi dengan menggunakan $1 \mathrm{ml}$ air untuk merusak dinding mikroenkapsulasi kemudian ditambahkan $9 \mathrm{ml}$ etanol $95 \%$ (v/v), divorteks selama 3 menit. Dilakukan penyaringan menggunakan kertas wathman No 1 dan dikualifikasi menggunakan metode perbedaan $\mathrm{pH}$. Jumlah Antosianin Permukaan (SAC) yaitu sampel $100 \mathrm{mg}$ ditambahkan $10 \mathrm{ml}$ etanol $95 \%(\mathrm{v} / \mathrm{v})$, divorteks selama 30 detik, disaring menggunakan kertas whatman no 1 dan dikualifikasi menggunakan metode perbedaan $\mathrm{pH}$. (Laokuldilok dan Kanha, 2016)

Efisiensi mikroenkapsulasi

$(\%)=1-\frac{\text { jumlah antosianin permukaan }}{\text { jumlah total anosianin }} \mathrm{x}$ 100

\section{Uji Stabilitas Penyimpanan}

Uji stabilitas penyimpanan di lakukan dengan menyimpan ekstrak zat warna pada temperature kamar yaitu $30^{\circ} \mathrm{C}$, pada temperatur $15^{\circ} \mathrm{C}$ dan suhu dingin dengan kondisi gelap selama 2 hari. Kemudain dilakukan pengenceran yaitu dengan cara pigmen cair dilarutkan sebanyak $2 \mathrm{~mL}$ dalam $100 \mathrm{~mL}$ air kemudian diukur absorbansinya pada panjang gelombang maksimum.

\section{Analisis Data}

Pengambilan data dilakukan dengan melakukan uji stabilitas ekstrak, formulasi ekstrak dan uji stabilitas dari mikrograf yang dihasilkan. Replikasi setiap pengujian dilakukan sebanyak 3 kali. Hasil yang diperoleh dibandingkan setiap formula.

\section{HASIL DAN PEMBAHASAN}

\section{Ekstraksi Antosianin dari Buah Buni}

Diperoleh ekstrak kental buah Buni berwarna merah keunguan dan memiliki bau khas aromatik serta rasa yang pekat dengan berat $47 \mathrm{~g}$ dari $300 \mathrm{~g}$ buah Buni segar yang berwarna ungu kehitaman yang telah dimaserasi dan menghasilkan rendamen ekstrak sebesar 15,6\%.

\section{Uji Kualitatif dan Fitokomia Antosianin}

Uji kualitatif antosianin dengan menggunakan KLT silika gel F 254 dengan pelarut asam asetat, asam asetat glasial dan asam format dapat dilihat bahwa warna yang terlihat pada lempeng menunjukkan warna spesifiksi dari antosianin yaitu merah, merah muda dan biru

Uji Fitokimia antosianin pada buah Buni dengan menggunakan HCL terjadi perubahan warna dari merah muda menjadi merah terang yang menunjukkan hasil positif bahwa antosianin pada kondisi asam memiliki gugus metoksi yang dominan menyebabkan warna merah dan relatif lebih stabil. Pada penambahan $\mathrm{NaOH}$ terjadi perubahan warna dari merah terang menjadi coklat kehitaman yang menunjukkan hasil positif bahwa antosianin pada kondisi basa menjadi berwarna gelap karena adanya gugus hidroksi yang dominan menyebabkan warna cenderung relatif tidak stabil.

\section{Hasil Pengujian Fitokimia Antosianin}

\begin{tabular}{|c|c|c|c|c|}
\hline No & $\begin{array}{c}\text { Kandungan } \\
\text { Kimia }\end{array}$ & Reaksi & $\begin{array}{c}\text { Perubahan } \\
\text { Warna }\end{array}$ & Hasil \\
\hline 1. & Antosianin & $\begin{array}{l}\text { Esktrak + } \\
\text { HCL } 2 \mathrm{M} \\
+ \\
\text { pemanasan } \\
5 \text { menit }\end{array}$ & $\begin{array}{l}\text { Merah } \\
\text { mudah } \\
\text { menjadi } \\
\text { merah } \\
\text { terang }\end{array}$ & Positif \\
\hline 2. & Antosianin & Ekstrak + & Merah & Positif \\
\hline
\end{tabular}




\begin{tabular}{|l|l|l|}
\hline & $\begin{array}{l}\mathrm{NaOH} \quad 2 \\
\mathrm{M}\end{array}$ & $\begin{array}{l}\text { terang } \\
\text { menjadi } \\
\text { coklat } \\
\text { kehitaman }\end{array}$ \\
\hline
\end{tabular}

\section{Analisis Kandungan Antosianin Total}

Penentuan antosianin total dilakukan dengan metode perbedaan $\mathrm{pH}$. Berdasarkan hasil pengukuran diperoleh antosianin total pada ekstrak buah Buni adalah 274,012 (mg/100g). Kandungan total antosianin yang didapatkan lebih tinggi dari hasil yang dilaporkan oleh Butkhup dan Samappito (2011), bahwa tingkat antosianin dalam buah Buni yang diekstraksi dengan matanol cair mengandung 2M HCL adalah 141, 94 $\mathrm{mg} / 100 \mathrm{~g}(0,14 \% \mathrm{~b} / \mathrm{b})$. Jumlah kandungan total antosianin yang diperoleh cukup tinggi hal ini terjadinya degradasi pigmen karena penggunaan pelarut yang mengandung asam sitrat dapat menyebabkan hidrolisis gugus asil yang labil, ko-pigmen, atau kompleks logam yang merupakan bagian dari bentuk asli antosianin yang berkontribusi untuk stabilitasnya. Penggunaan asam sitrat, sebagai asam organik yang lebih lemah, dapat meminimalkan degradasi pigmen. Selain itu, asam sitrat juga kurang korosif daripada $\mathrm{HCl}$.

\begin{tabular}{|c|c|c|c|}
\hline \multirow{2}{*}{$\begin{array}{c}\text { Panjang } \\
\text { gelombang } \\
(\mathrm{nm})\end{array}$} & \multicolumn{2}{|c|}{ Absorbansi } & \multirow{2}{*}{$\begin{array}{c}\text { Total } \\
\text { antosianin( } \\
\mathrm{mg} / 100 \mathrm{~g})\end{array}$} \\
\hline & $\mathrm{pH} \quad 1,0$ & $\begin{array}{l}\mathrm{pH} \\
4,5\end{array}$ & \\
\hline 523 & 0,414 & 0,116 & \multirow{2}{*}{274,012} \\
\hline 700 & 0,172 & 0,033 & \\
\hline
\end{tabular}

\section{Penentuan Intensitas Warna dari Ekstrak Buah Buni}

Pada penentuan intensitas warna dari ekstrak buah Buni ditentukan dalam panjang gelombang maksimum $523 \mathrm{~nm}$ dan $700 \mathrm{~nm}$. Hasil intensitas warna menunjukkan bahwa intensitas warna ekstrak buah Buni adalah 0,244 dan 0,213 yang menunjukan adanya intensitas warna yang cukup untuk dapat dijadikan sebagai pewarna dalam makanan
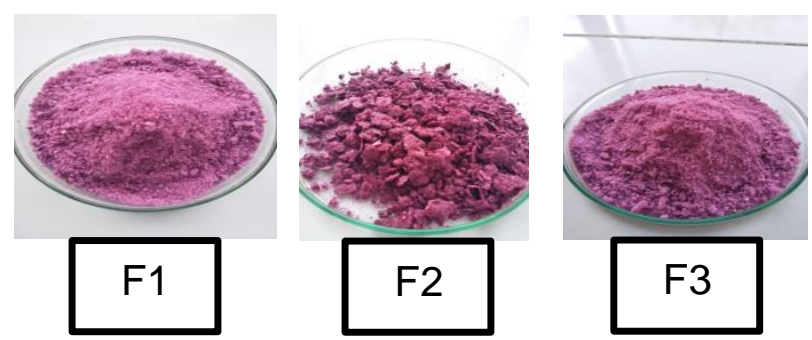

\section{Uji Stabilitas dari Ekstrak Buah Buni}

Pada pengujian stabilitas antosianin dengan perlakuan $\mathrm{pH}$, ekstrak diambil sebanyak $2 \mathrm{ml}$ kemudian ditambahkan 100 $\mathrm{ml}$ larutan buffer asam sitrat dengan $3 \mathrm{pH}$ yang berbeda (4, 5 dan 7).

Pada antosianin ekstrak buah Buni perlakuan $\mathrm{pH} \quad 4$ menghasilkan warna merah sedangkan pada $\mathrm{pH} \quad 5$ dan 7 berwarna hijau sampai biru. Pada suasana asam antosianin berada dalam bentuk garam flavilium berwarna merah yang lebih stabil sedangkan Ketika pH naik ke nilai $\mathrm{pH}$ 4-5 atau $\mathrm{pH}$ semakin ditingkatkan warna ekstrak menjadi memudar. Hal ini menunjukkan bahwa antosianin lebih stabil pada kondisi asam dari pada kondisi basa.

\section{Formulasi Mikrograf dari Ekstrak Buah Buni}

Dari hasil formulasi ekstrak buah Buni dengan metode frezee drying dengan menggunakan maltodekstrin sebagai penyalut diperoleh mikrokapsul antosinin. Pada formula 1 diperoleh mikrokapsulyang berwarna merah muda dengan berat 13,4 gram, pada formula 2 mikrograf yang dihasilkan berwarna merah keunguan dengan berat 16,6 gram, dan pada formula 3 mikrograf yang dihasilkan 
berwarna merah terang dengan berat 16,9 gram.

\begin{tabular}{|c|c|}
\hline \multirow{2}{*}{$\begin{array}{c}\text { Panjang } \\
\text { gelombang } \\
(\mathrm{nm})\end{array}$} & Absorbansi \\
\hline & $\begin{array}{l}\text { Buffer Posfat-Asam } \\
\text { Sitrat } \mathrm{pH} 3\end{array}$ \\
\hline 523 & 0,244 \\
\hline 700 & 0,213 \\
\hline
\end{tabular}

ket :

F1 : Formula 1 konsentrasi ekstrak $1 \%$ F2 : Formula 1 konsentrasi ekstrak $2 \%$ F3: Formula 1 konsentrasi ekstrak $3 \%$

\section{Analisis Scanning Electron Microscopy} (SEM)

Hasil analisis sem formula terlihat pada gambar, formula 1 menunjukkan hasil mikrostrukturnya memiliki pori yang berukuran seragam dan terdistribusi secara merata, kondisi ini memungkinkan antosianin terperangkap lebih banyak dalam matriks.
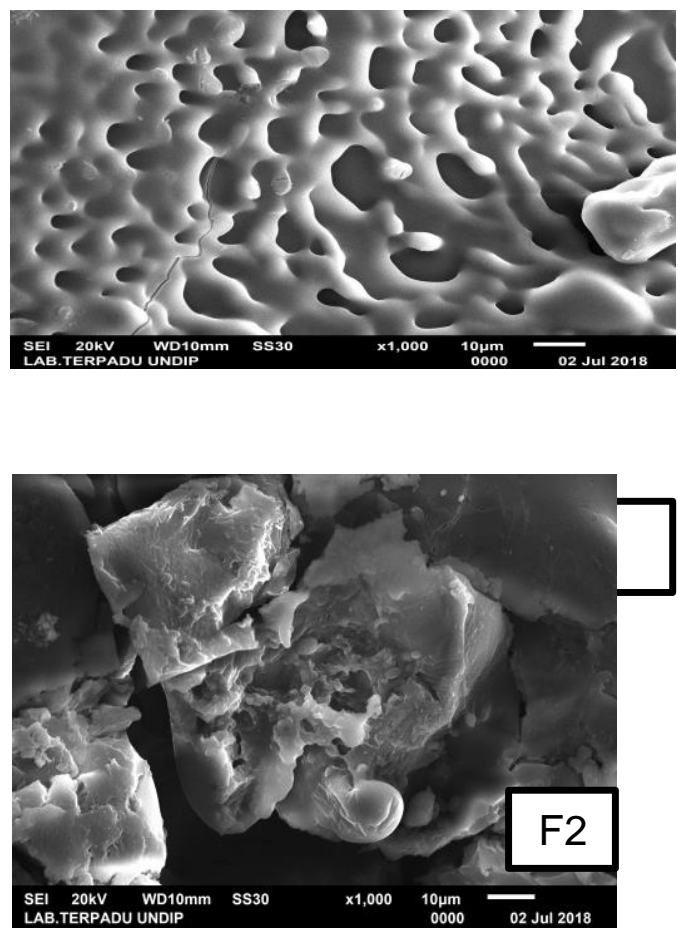

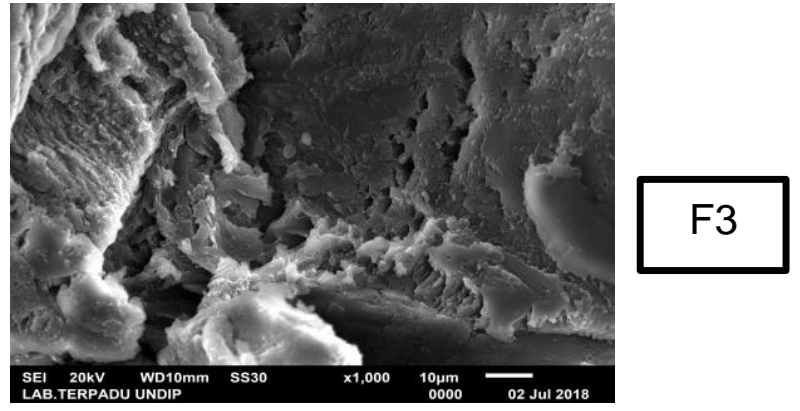

Efisiensi Mikroenkapsulasi

Dalam penentuan antosianin total pada formula 1,2 dan 3 dilakukan pengukuran dengan metode perbedaan $\mathrm{pH}$ yang diukur absorbansinya pada $510 \mathrm{~nm}$ dan $700 \mathrm{~nm}$. Pada formula 1 didapatkan nilai mikroenkapsulation effieiency (\%) yaitu78,26 (mg/100mL), pada formula ke 2 didapatkan nilai MEE (\%) yaitu $15,73(\mathrm{mg} / 100 \mathrm{~mL})$, pada formula ke 3 didapatkan nilai MEE (\%) yaitu 12.71 (mg/100mL). Dari data tersebut dapat dilihat bahwa nilai MEE yang paling tinggi pada Formula 1 yaitu ekstrak dengan konsentrasi $1 \%$, dan berbeda jauh dengan Formula1 dan 2.

\section{Efisiensi mikrokapsul}

\begin{tabular}{|l|l|c|l|}
\hline Formula & TAC & SAC & MEE(\%) \\
\hline F1 & 0,046 & $-0,026$ & 78,26 \\
\hline F2 & 0,089 & $-0,004$ & 15,73 \\
\hline F3 & 0,118 & $-0,005$ & 12.71 \\
\hline
\end{tabular}

Ket :

F1 : Formula 1 konsentrasi ekstrak $1 \%$ F2 : Formula 2 konsentrasi ekstrak $2 \%$ F3 : Formula 3 konsentrasi ekstrak $3 \%$

\section{Uji Stabilitas Penyimpanan mikrograf}

Pengujian stabilitas mikrograf antosianin terhadap perlakuan $\mathrm{pH}$

Pengujian stabilitas mikrograf antosianin terhadap perlakuan $\mathrm{pH}$ dilakukan pada $\mathrm{pH}$ 3, 4, 5 dan 6. Adanya perlakuan $\quad \mathrm{pH}$ mempengaruhi totalantosianin, dimana semakin tinggi nilai $\mathrm{pH}$ maka kadartotal antosianin 
semakin menurun. Pada $\mathrm{pH} 3$ menunjukkan intensitas warna antosianin rentang antara 0,182 hingga 0,433 sedangkan pada $\mathrm{pH} 4$ rentang antara 0,053 hingga 0,383 , pada $\mathrm{pH} 5$ rentang antara 0,022 hingga 0,224 dan pada $\mathrm{pH} 6$ menunjukka intensitas warna. Hal ini menunjukka bahwa adanya perlakuan $\mathrm{pH}$ mempengaruhi intensitas warna antosianin dimana semakin tinggi nilai $\mathrm{pH}$ maka kadar antosianin semakin menurun.

\section{KESIMPULAN}

Formula dengan konsentrasi ekstrak $1 \%$ memiliki nilai efisiensi mikrokapsul terbesar yaitu 78,26\% dan mikrostruktur yang seragam sert terdistribusi merata.

\section{UCAPAN TERIMA KASIH}

Dirjen

Belmawa

KemenRistekDikti PKM-P 2017.

\section{DAFTAR PUSTAKA}

Citramukti, I. 2008. Ekstraksi dan Uji Kualitas Pigmen Antosianin Pada Kulit Buah Naga Merah (Hylocereus costaricensis), (Kajian Masa Simpan Buah dan Penggunaan Jenis Pelarut), Skripsi JurusanTHP Universitas Muhammadiyah Malang; Malang.

Elsa Tresia, Kusuma sayuti, dan Andhika Permata, 2016. Pengaruh Konsentrasi Maltodekstrin dalam Pembuatan Pewarna Alami Serbuk Kulit Buah Jambalang (Syzygium cumini) Menggunakan Spray Dryer.

Fera Amelia, Galih Nur Afnani, Arini Musfiroh, Alia Fikriyani, Sisca Ucche and Mimiek Murrukmihadi.
2013 . Extraction and Stability Test of Anthocyanin from Buni Fruits (Antidesma bunius L.) as an Alternative Natural and Safe Food Colorants,Journal of Food and Pharmaceutical Sciences, 49-52.

Lydia ninan lestario, elisabeth rahayuni, kris herawan timotius, 2011, kandungan antosianin dan identifikasi antosianin dari kulit buah jenitri (Alaeocarpus angustifolio Blume) AGRITECH Vol 31: 94.

Margareta Novi Wijayanti, 2016, Uji Aktivitas Antioksidan dan Penetapan Kadar Fenolik Total Ekstrak Etanol Buah Buni (Antidesma bunius L.) dengan Metode 2,2-diphenyl-1picrylhydrazyl (DPPH) dan Metode Folin-Ciocalteu.

Ni Ketut Meidayanti Putri, I Wayan Gede Gunawan, dan I Wayan Suarsa, 2015, Aktivitas Antioksidan Antosianin Dalam Ekstrak Etanol Kulit Buah Naga Super Merah (Hylocereus costaricensis) dan Analisis Kadar Totalnya : Jurnal Kimia ISSN 1907-9850 vol 9 (2) 254-248.

Nursaerah, R, Mempelajari Ekstraksi Antosianin dari Kulit Buah Manggis (Garcinia mangostana L.) Dengan Berbagai Jenis Pelarut, Skripsi, Fakultas Teknologi Pangan Universitas Pasundan, Bandung, 2010.

Supriyadi dan A. Sakha Rujita, 2012, Karakterisatik Mikrokapsul Minyak Atsiri Lengkuas dengan 
$\begin{array}{ll}\text { Maltodekstrin } & \text { Sebagai } \\ \text { Enkapsulan Tekno } & \text { Industri }\end{array}$

Pangan.

Sri Sugiyatmi, 2006, Hubungan Pengetahuan dan Sikap Produsen Kerupuk Terhadap Penggunaan Pewarna Rhodamin B Pada Kerupuk Yang Diproduksi di Desa Kalitekuk Kecamatan Karanganyar Kabupaten Demak, Skripsi S1 Gizi Kesehatan Masyarakat:universitas Muhammadiyah Semarang.
Thunnop Laokuldilok and Nattapong Kanha, 2016, Microencapsulation of Black Glutinous Rice Anthocyanins Using Maltodextrins Produced from Broken Rice Fraction As Wall Material by Spray Drying and Freeze Drying. Journal of food processing and preservation ISSN 1745-4549 : 3 . 